\title{
Structure of English Locative Inversion
}

\author{
I Ketut Widi Adnyana*, Yana Qomariana \\ English Department, Faculty of Arts, Udayana University \\ [widiadnyana@outlook.com],[yqomariana@yahoo.com] \\ Denpasar, Bali, Indonesia \\ *Corresponding Author
}

\begin{abstract}
A sentence structure involves the packaging of meaning. Words and their order decide the meaning of a sentence conveyed. This study discussed two points of problems. The first one is locative inversion structure in sentences taken from Corpus of Contemporary American English. The other problem is the constraints of locative inversion in the English grammar. The problems are discussed based on the theory of inversion by Hewings (2005). Method used to collect the data was documentation method. The analysis was conducted using descriptive qualitative method. The result of the analysis is shown using informal method. As results, this study shows that locative inversion structure is different from canonical structures. It has a distinct feature contrasting it with canonical structure. It also has several constraints regarding subject, predicate, and salient information affecting its formation.
\end{abstract}

Keywords: sentence structure, inversion, locative inversion

\begin{abstract}
Abstrak
Sebuah struktur kalimat meliputi wadah dari arti. Kata-kata dan urutannya dalam kalimat menentukan apa makna yang disampaikan oleh kalimat tersebut. Studi ini membahas dua poin masalah. Poin pertama membahas mengenai struktur dari kalimat inversi lokatif yang diambil dari Corpus of Contemporary American English. Masalah kedua adalah mengenai batasan yang dimiliki inversi lokatif pada kaidah Bahasa Inggris. Kedua masalah tersebut dibahas berdasarkan teori kalimat inversi oleh Hewings (2005). Metode yang digunakan dalam mengumpulkan data adalah metode dokumentasi. Analisis pada studi ini dilakukan berdasarkan metode deskriptif kualitatif. Hasil dari analisis tersebut ditampilkan dengan metode informal. Sebagai hasilnya, studi ini menunjukkan bahwa struktur inversi lokatif berbeda dengan struktur resmi. Terdapat fitur khusus yang membedakannya dengan stuktur resmi. Ditemukan juga beberapa batasan yang berhubungan dengan subjek, predikat, dan informasi utama yang mempengaruhi pembentukannya.
\end{abstract}

Kata kunci: struktur kalimat, inversi, inversi lokatif

\section{INTRODUCTION}

Every language has a unique way of delivering thoughts. The same idea might be conveyed differently in every language. In expressing meaning, words are ordered in a particular structure. The structure is bound by rules also known as syntax.
It governs words arrangement either in the form of a clause or a sentence. Meaning conveyed by a sentence has a great dependence on its structure. It could be said that a structure also conveys meaning. Two sentences constructed by the same elements 
might have different meaning if they are arranged differently (VanValin, 1997).

English is a subject-verb-object language meaning that its sentences are constructed using SVO pattern. In English, a sentence starts with a subject, a verb follows after, and it ends with an object. However, this structure can be reversed in order to achieve some kind of meaning. For instance, in asking question, the position of several elements has to be switched. In a simple question like Are you okay?, the subject and verb switch their canonical position. This phenomenon is known as inversion (Bresnan and Kanerva, 1989; Green, 1980; Culicover and Winkler, 2008).

Locative inversion is a type of inversion. The term locative subsumes a wide range of spatial locations, directions, and paths (Bresnan, 1994; Nakajima, 2000). It functions to emphasize information regarding location in a sentence. Its form abandons the canonical structure. It is constructed based on the importance of information. In this case, locative information is considered salient. It works by fronting the locative information and switching the position of subject and verb. As a result, a salient information is placed in the front of the sentence, a verb follows after, and a subject ends the sentence (Hewings, 2005; Prado-Alonso and AcunaFarina, 2010).

There are superficially similar constructions such as subject-auxiliary inversion, there- insertion, and preposing. However, these constructions are different from locative inversion as it has distinctive features (Levine, 1989; Penhallurrick, 1984)

This study aimed at analyzing locative inversion structure in sentences taken from COCA. Furthermore, it also aimed at analyzing the constraints of locative inversion in the English grammar.

\section{MATERIAL AND METHOD}

The data analyzed were collected from Corpus of Contemporary American English (COCA) accessed through https://www.english-corpora.org/coca. Mark Davies, professor of Corpus Linguistics at Brigham Young University, is the man behind the largest corpus of American English. COCA is composed of texts from various genres. It consists of more than 560 million words from 220.225 texts from 1990 through 2017. It provides American English texts from varied sources (e.g. magazine, newspaper, TV program) in both oral and written form. The texts are available in five genres which are spoken, fiction, popular magazines, newspapers, and academic journals.

The data were collected using documentation method and note taking technique. They were searched and grouped based on locative inversion types.

The collected data were analyzed using descriptive qualitative method. The analysis is couched by Hewings's theory of inversion. It is done in stages. It began with grouping the data based on locative inversion types. Afterwards, the structures of the sentences were analyzed and drawn into tree diagram to see its construction. Having done the previous stages, the constraints of locative inversion were analyzed. Due to descriptive form of the data, the analysis was presented using an informal method.

\section{THEORETICAL BASIS}

\section{Literature Review}

Birner (1994) discusses inversion as information-packaging mechanism, and proving that felicitous inversion depends on information's relative discourse-familiarity represented by preposed and postposed constituents. The result shows that initial position of inversion tends to be reserved for information which is salient, and that preposed element in inversion should not be newer in the discourse than the postposed element. However, it needs further explanations on variations of inversion as it only argued on the information status, and explanations on the syntactic structure of inversion to show what information is allowed to be in the initial position.

Birner and Ward (1992) discuss the interaction of syntactic and pragmatic constraints towards the interpretation of VP inversion. Theoretically, this study is done using theories of Stump (1985), Hartvigson and Jakobsen (1974), Dowty (1979), and Green (1980). Qualitative method is used in doing this study. The result shows that 
competition of forms does affect the implicature associated with the canonicalword-order. It also claims that verbs other than be used in inversion should represent shared knowledge at the time of its utterance. However, this study lacks number of examples to show that this study is applicable in various cases.

\section{Inversion}

Inversion is reversion of certain elements in a sentence from their canonical position. Common form of inversion is interrogative sentence. In questions, auxiliary and subject switch their position. However, it does not cover question asking for subject because there is no inversion occurred. For instance, Who did this? This question asks for the subject of the sentence. As can be seen, there are no elements reversed.

Inversion can also be understood as information fronting. Sentences in English have a canonical pattern which is subjectverb-object construction. However, this pattern can be reversed in order to give emphasis on particular information. It is known as inversion. It is a word arrangement in which importance of information is the basis of the word order. Thus, sentences using inversion construction are not arranged in subject-verb-object order. The information considered salient is put in the front, while the rest of information follows after. Distinct feature of this construction is the reversal of subject and predicate position (Hewings, 2005; Dorgeloh, 1994).

\section{Locative Inversion}

Locative inversion is a type of inversion. In this type of inversion, the predicate of the sentence has to be a verb. Its structure is marked by reversal position of subject and verb. Salient information is put in the initial position of the sentence. Verb of the sentence comes before subject, and is put after the salient information. It is divided into two types which are static locative inversion and directive locative inversion (Hewings, 2005).

\section{FINDINGS AND DISCUSSION}

There are two points of discussions in this study. The first one concerns the structure of locative inversion. The second point discusses the constraints of locative inversion in the English grammar.

\section{Structure of Locative Inversion}

Locative inversion is divided into two based on types of location contained in the sentence. The first one static locative inversion and the second one is directive locative inversion.

\section{Static Locative Inversion \\ Data 1}

In the hall stood Mary Gamble (COCA, FIC, 2013).

There are three elements in the sentence. The first element is PP in the hall, the second element is verb stood, and the last one is noun Mary Gamble as subject. This data is classified into static type as the salient information is in form of static location. Inversion occurs in the underlined part. The sentence begins with $\mathrm{PP}$ as the salient information, predicate of the sentence follows after, and the subject of the sentence comes last showing that the position of subject and predicate is switched. The structure of the sentence is presented by the tree diagram below.

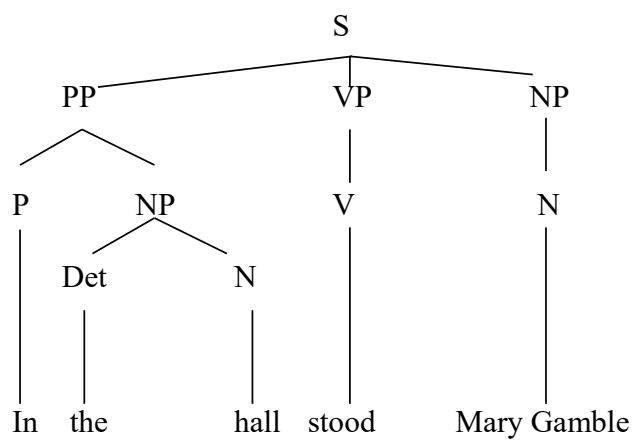

\section{Data 2}

In the house was a demon (COCA, FIC, 2010).

The sentence is formed by three elements. The first element is $\mathrm{PP}$ in the house, the second one is verb was, and last element is NP a demon as subject. This data is classified into static type as the salient information is in form of static location represented by PP. Inversion occurs in the underlined part. The sentence begins with PP in the house signaling that it is the focus of the sentence. The predicate of the sentence is 
placed right after PP. The subject of the sentence is placed last showing that the position of subject and predicate is reversed. The structure of the sentence is presented by the tree diagram below.

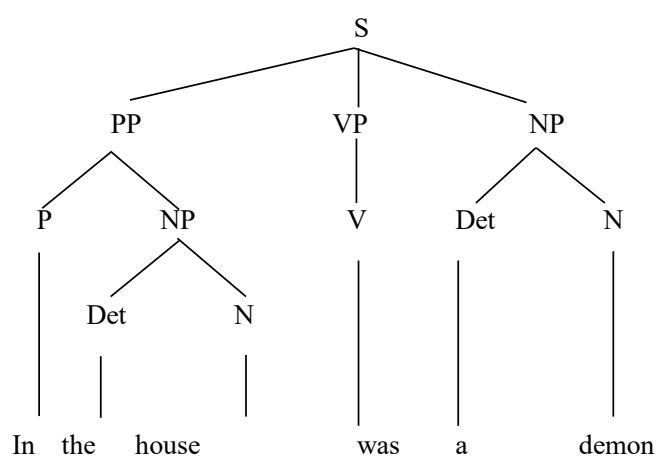

Data 3

On the table stood vodka (COCA, FIC, 2007).

There are three elements in the sentence. The first element is PP on the table, the second one is verb stood, and last element is noun vodka as subject. This data is classified into static type as the salient information is in form of static location represented by PP. Inversion occurs in the underlined part. The sentence begins with PP on the table as the salient information. Predicate stood is placed right after PP. The subject of the sentence comes last. The structure of the sentence is presented by the tree diagram below.

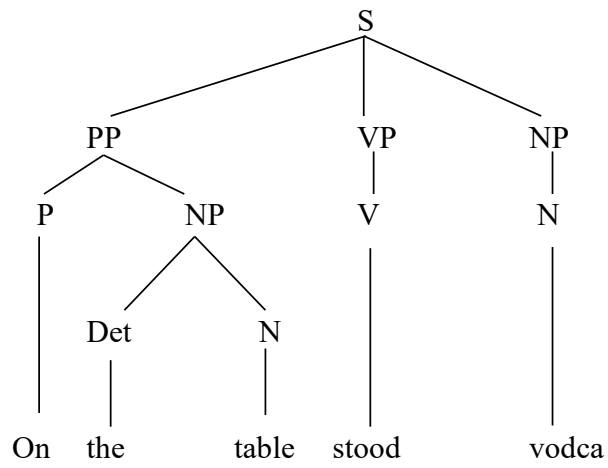

\section{Directive Locative Inversion}

Data 4

There goes my baby (COCA, SPOK, 2015).

There are three elements constructing the sentence. They are adverbial there, verb goes, and NP my baby as subject. This sentence is classified into directive locative inversion because the salient information is an adverbial that expresses direction of movement. Inversion occurs in the underlined part. The sentence begins with adverbial as the salient information. Predicate of the sentence follows after adverbial. The subject of the sentence is placed last as the position of subject and predicate is inverted. The structure of the sentence is presented by the tree diagram below.

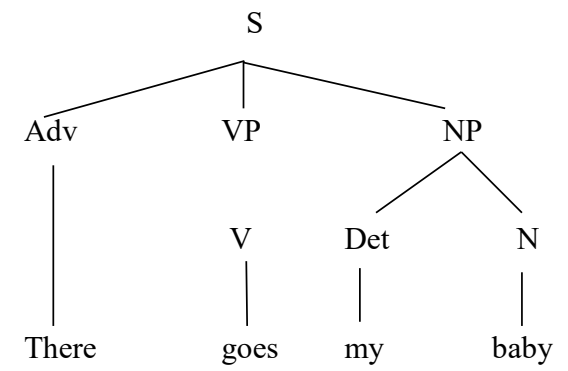

\section{Data 5}

Up went the kite (COCA, MAG, 1999).

Three elements construct the sentence. The first element is adverbial $u p$, the second element is verb went, and the last element is NP the kite as subject. This sentence is classified into directive locative inversion because the salient information is an adverbial that expresses direction of movement. Inversion occurs in the underlined part. The sentence begins with adverbial as the salient information. Predicate of the sentence follows after salient information. The subject of the sentence is placed last as the position of subject and predicate is inverted. The structure of the sentence is presented by the tree diagram below.

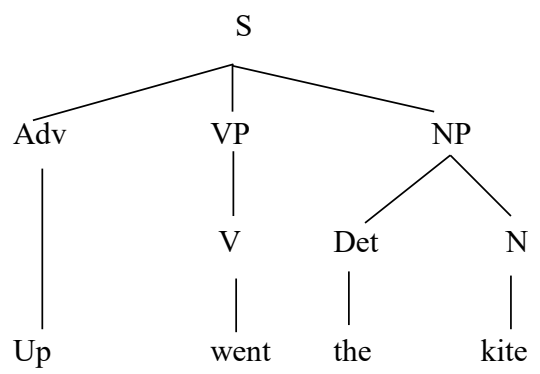

Data 6

Out go the bad thoughts (COCA, FIC, 1993).

The sentence is formed by three elements that are adverbial out, verb go, and NP the bad thoughts as subject. This 
sentence is classified as directive locative inversion because the salient information is an adverbial expressing direction of movement. Inversion occurs in the underlined part. The sentence begins with adverbial as the salient information. The predicate of the sentence follows after adverbial. The subject of the sentence is placed last as the position of subject and predicate is reversed. The sentence structure is presented by the tree diagram below.

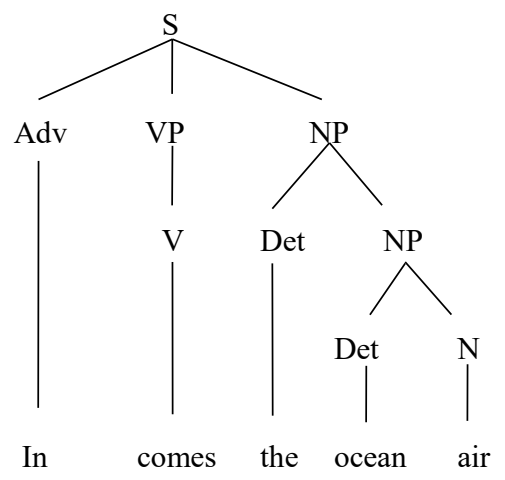

\section{Constraints of Locative Inversion in the English Grammar}

Locative inversion is a unique grammar construction as its structure is different from canonical word order structure. Some SVO clauses can be formed into locative inversion and vice versa, while the rest cannot. Theoretically, clauses that can be turned into locative inversion should have verb as the predicate. However, several aspects in forming a locative inversion clause are also identified. Forty data are used to identify the constraints of locative inversion construction. Following points constrain the formation of locative inversion:

\section{Highlighted element contains locative information \\ Data 7}

On the table sat a plate of the same sugar cookies (COCA, FIC, 2004).

\section{Data 8}

In comes the option of the death penalty (COCA, SPOK, 2012).

\section{Data 9}

In went big piles of blankets and comforters (COCA, MAG, 1996).

The first aspect identified is salient information of inversion. The underlined part of the sentences is the focused sentence.
They are in form of prepositional phrase, and adverbial expressing direction of movement. All of the highlighted elements from all types of locative inversion are similar in which they contain information regarding place or location of the action.

\section{Clause uses intransitive verb and in form} of simple present or simple past

\section{Data 10}

On the table sat the cake (COCA, FIC, 2014).

\section{Data 11}

In comes Operator Jones (COCA, FIC, 2016).

Data 12

There goes my baby (COCA, SPOK, 2015).

The second aspect identified is predicate of the sentence. The underlined part of the data is predicate in form of verb. There is absence of direct object in every datum. All of the predicates are intransitive verbs which do not have direct object. Furthermore, in forming locative inversion, predicate should be in the form of full verb leading to the absence of auxiliary. The verb be can also act as full verb if it is not followed by other verb. Thus, verbs in locative inversion are in the form of only full verb in simple past and simple present which do not require auxiliary. This constraint is in line with Coopman (1989), Birner (1995), Hartmann (2011) and Wit (2016) analysis on verb used in locative inversion.

\section{Subject of the sentence is not pronoun Data 13}

On the table sat a plate of the same sugar cookies (COCA, FIC, 2004).

\section{Data 14}

In went big piles of blankets and comforters (COCA, MAG, 1996).

\section{Data 15}

In the box were two sets of identical and adorable baby clothes (COCA, MAG, 2010).

The third aspect identified is subject of the sentence. The underline part of the data is the subject of the sentence. Subjects shown in data above are in form of noun and noun phrase. There is absence of pronoun as subject. 


\section{The sentence is affected by subject-verb agreement rules}

Subject-verb agreement is a rule that binds subject and predicate. It means that both element should agree in number. When the subject is singular, the predicate should be in singular form, and when the subject is plural, the predicate should be in plural form. Locative inversion sentence is also affected by this agreement. Though the position is reversed, the verb should agree with the number of the subject. This rule also applies on verb be (Bock et al., 2006).

The subject in locative inversion is not decided based on its position. It means that locative information cannot be counted as the subject though it is placed in the front. The subject of the sentence is still the nominative case. Thus, the one affecting the agreement is nominative case (Culicover and Levine, 2011; Bruening, 2010; Broekhuis, 2005).

\section{Data 16}

In the box were two sets of identical and adorable baby clothes (COCA, MAG, 2010).

The subject of sentence in data 16 is two sets of identical and adorable baby clothes and its verb is were. Both elements agree in number proven by their form. As the subject is in plural form, the verb is also in plural form.

\section{CONCLUSION}

Based on the foregoing analysis, it can be concluded that the structure of locative inversion is different compared to canonical structure. The sentence does not order in SVO pattern but based on the importance of information. The most important information is put in the front of the sentence. Following after is sentence predicate which has to be a full verb. The sentence ends with sentence subject.

The second point of conclusion is the constraints of locative inversion construction in the English grammar. All locative inversion sentence can be formed into canonical structure however not all sentences can be formed into locative inversion. It is because locative inversion cannot be formed using any verb or any noun. There are four constraints identified in locative inversion construction. The first constraint is salient information in this construction has to be locative information. It can be in the form of adverbial, and prepositional phrase. The second one is predicate in locative inversion. It has to be full verb and only intransitive verbs can be used as they do not require object. They have to be in simple present or simple past form because the verb cannot use an auxiliary. Verb be can also be included as long as it stands on its own and is not followed by other verbs. Third constraint is sentence subject can only be full noun and cannot be replaced by a pronoun. Lastly, sentence subject and predicate are bound by subject-verb agreement. They have to agree in number. If subject is singular, predicate has to be singular, and if subject is plural, predicate has to be plural.

\section{REFERENCES}

Birner, B. J. (1994). Information Status and Word Order: An Analysis of English Inversion. Language, Vol. 70.2, 233359.

Birner, B. J. (1995). Pragmatic Constraints on the Verb in English Inversion. Lingua, Vol. 97.4, 233-256.

Birner, B. J. and Ward, G. L. (1992). On the Interpretation of $\mathrm{VP}$ Inversion in American English. Journal of Linguistics, Vol. 28.1, 1-12.

Bock, K., Cutler, A., Eberhard, K. M., Buttefield, S., Cutting, J. C., and Humphreys, K. R. (2006). Number Agreement in British and American English: Disagreeing to Agree Collectively. Language, Vol. 82.1, 64113.

Bresnan, J. (1994). Locative Inversion and the Architecture of Universal Grammar. Language, Vol. 70.1, 72131.

Bresnan, J. and Kanerva, J. M. (1989). Locative Inversion in Chichewa: A Case Study of Factorization in Grammar. Linguistic Inquiry, Vol. 20.1, 1-50. 
Broekhuis, H. (2005). Locative Inversion in English. Linguistics in the Netherlands, Vol. 22, 49-60.

Bruening, B. (2010). Language-Particular Syntactic Rules and Constraints: English Locative Inversion and DoSupport. Language, Vol. 86.1, 43-84.

Coopmans, P. (1989). Where Stylistic and Syntactic Processes meet: Locative Inversion in English. Language, Vol. $65.4,728-751$.

Culicover, P. W. and Winkler, S. (2008). English Focus Inversion. Journal of Linguistic, Vol. 44.3, 625-658.

Culicover, P. W. and Levine, R. D. (2011). Stylistic Inversion in English: A Consideration. Natural Language and Linguistics Theory, Vol. 19.2, 283310 .

Dorgeloh, H. (1994). Viewpoint and the Organisation of Informative Discourse: On the Discourse Function of Full Inversion in English. Turku Conference. Turku August $10^{\text {th }}-14^{\text {th }}$.

Green, G. M. (1980). Some Wherefores of English Inversions. Language, Vol. 56.3, 582-601.

Hartmann, J. M. (2011). Predicate Inversion and English There- Sentences. Acta Linguistica Hungarica, Vol. 58.3, 221-240.

Hewings, M. (2005). Advanced Grammar in Use. Cambridge University Press.

Levine, R. D. (1989). On Focus Inversion: Syntactic Valence and the Role of a SUBCAT List. Linguistics, Vol. 27.6, 1013-1055.

Nakajima, H. (2000). Verb Second, Locative Inversion and Topicalization. Linguistics Analysis, Vol. 30, 7-24.
Penhallurrick, J. (1984). Full-verb Inversion in English. Australian Journal of Linguistics, Vol. 4.1, 33-56.

Prado-Alonso, C. and Acuna-Farina, J. C. (2010). A Comprehensive Study of Full-verb Inversion in English. Folia Linguistica, Vol. 44.2, 509-554.

Van Valin, R. D. and Lapolla, R. J. (1997). Syntax: Structure Meaning and Function. Cambridge University Press.

Wit, A. D. (2016). The Relation between Aspect and Inversion in English. English Language and Linguistics, Vol. 20, 107-128. 